upon as constituting a high rate, but this figure was not intended to be binding. The opening lecture was given by Dr. A. H. Cottrell, who dealt with some fundamental principles. The detailed papers were classified under the following headings : experimental techniques; metal working ; impulse loading and stress waves ; non-metallic materials ; and basic properties. The matter presented forms a comprehensive, useful and interesting account of the subject. Synopses of the papers are given in the programme of the conference, and advance copies of the papers are available from the Institution of Mechanical Eng. ineers. Ultimately, bound and indexed volumes of the proceedings, including the discussions, will be published.

\section{National Museums of Southern Rhodesia}

THE annual report for 1956 of the National Museums of Southern Rhodesia (Pp. 21. Bulawayo: National Museums of Southern Rhodesia. n.p.) records that although plans for a new building for the National Museum in Bulawayo were completed during the year, owing to the suggestion that the building would be better sited in North Park, further developments have been suspended while discussions continue. The Trustees favour the North Park site. At Salis. bury a new building is urgently required for the Queen Victoria Museum. In the meanwhile, under the new curator, Col. H. L. Boultbee, some of the galleries have been modermized and every effort has been made to gain the interest and support of the public. Certain limitations are imposed by lack of staff and accommodation, but the Museum is compensating for these handicaps by its activities in other directions, such as the formation of the 'Friends of the Museum', a vigorous schools service and lectures by the staff to many cognate organizations.

Commonwealth Fund Fellowships for Advanced Study and Travel in the United States

A Number of Commonwealth Fund Fellowships are again being offered by the Commonwealth Fund, New York, to British subjects for study and travel in the United States. All expenses of study, travel and living will be met, with some adjustment of stipend for married men. The fellowships, which are open to British men or women who have not previously worked for more than a few months in the United States, are in six categories : General, twenty fellowships to graduates of a university in Great Britain or Northern Ireland; candidates must be available in London for interview in March 1958; age, 23-32 ; tenure, $12-21$ months; applications by December 16. Home Civil Service, five fellowships to permanent members in the higher ranks of the Civil Service in Great Britain, three for the admin. istrative grades and two for the scientific and professional grades; age, preferably less than 40 ; tenure, 9-15 months; applications by December 10 to the Treasury. Australian and New Zealand Civil Services, five fellowships to Civil servants in the Governments of Australia and New Zealand; age, less than 40 ; tenure, $9-15$ months; applications by November 1 to Dr. H. Carlyle Forster, Box 4079, Melbourne, or the Public Service Commission, Wellington, N.Z., respectively. Oversea Civil Service, two fellowships to Civil servants in the Governments of British Colonies, Protectorates and Trust Territories; age, less than 40 ; tenure, 9-15 months; applications by November 17 to the Colonial Office, London. Journalism, three fellowships to journalists, practising in the United Kingdom and engaged on the opinion-making or broadly editorial side of their profession; age, 23-35; tenure, 9-15 months; applications by December 31. American Studies, four fellowships to faculty members appointed to or holding posts in American studies in universities in the United Kingdom; candidates to be nominated by their universities; tenure, 4-15 months. Application forms and further information may be obtained through British universities or through Government departments, or from The Warden, Harkness House, 35 Portman Square, London, W.1.

\section{The Corday-Morgan Commonwealth Fellowship}

The Chemical Society invites applications from citizens of any country within the British Commonwealth for the Corday-Morgan Commonwealth Fellowship, to be awarded for post-doctorate (or equivalent) study in any branch of chemistry. It will be tenable for one year in some part of the British Commonwealth other than that in which the candidate received his scientific education, at any university, research institution or other place of study approved by the Corday-Morgan Memorial Fund Executive. The value of the Fellowship will be $£ 700$ per annum, but additional allowances may be granted in appropriate cases for travel, university fees, etc. The appointment will date from October 1,1958 , or such other date as may be arranged. Application forms may be obtained from the Secretary, Corday-Morgan Memorial Fund Executive, c/o Chemical Society, Burlington House, London, W.1. Applications must be received by the Secretary not later than March 1 , 1958.

University News :

Bristol

DR. H. G. H. Kearns, at present reader in entomology in the University, has been appointed director of the Long Ashton Research Station and to a professorship in the University.

Khartoum

THE following appointments have recently been announced: Dr. J. B. Lynch, lecturer in pathology, University of Liverpool, to the chair of pathology; Mr. Donald Portway, lately Master of St. Catharine's College, Cambridge, to the chair of mechanical engineering.

\section{Announcements}

PRof. T. A. BENNET-CxaRK, professor of botany in the University of London (King's College), and Prof. E. G. Cox, professor of inorganic and structural chemistry in the University of Leeds, have been appointed to fill vacancies in the membership of the Agricultural Research Council caused by the retirement of Prof. E. J. Maskell and Prof. L. P. Pugh. Prof. P. B. Medawar has been re-sppointed for a further term.

A course of six lectures on "The Technique of Technical Writing" will be given at the Borough Polytechnic, Borough Road, London, S.E.1, on Fridays at 2.30 p.m. beginning on October 11, by G. Parr, technical director of Chapman and Hall, Ltd. The fee for the course is ten shillings. Further details may be obtained from the Secretary of the Polytechnic. 